\title{
Analysis of Hunan Traditional Theater Building
}

\author{
Yuan Gao, Xiaofeng Li, Yuhan Dong and Xiaojun Li \\ Huazhong University of Science and Technology, China
}

\begin{abstract}
Hunan is located in the Yangtze River Basin in China. The ancestral theater building is a type of architecture in this area during the Ming and Qing Dynasties. In this paper, the central, east and south part of Hunan in which the traditional ancestral theater buildings are widely distributed is selected as a clue. The architectural form of the ancestral theater buildings is also discussed. Meanwhile, general regularity characteristics of the overall layout, substantial elements and spatial pattern are analyzed. Finally, the related factors of the architectural form are proposed in order to provide some enlightenment for the follow up study.
\end{abstract}

Keywords: Hunan, traditional ancestral theater buildings, architectural form, related factors

\section{The Background and General Situation of Traditional Ancestral Theater Buildings in Hunan}

\subsection{The Background of Traditional Ancestral Theater Buildings}

There used to be a large scale of immigration along the the Yangtze River during the Ming and Qing Dynasties. When the immigrants arrived at the west of Hunan, most of them kept the original way of life. Common blood ties prompted them to construct ancestral halls to maintain the unity and cohesion of the tribe. As the core of the tribe, the ancestral halls were used to educate people and there were often theater buildings in the ancestral halls. With the prosperous of ancestral halls, the theater buildings gradually became an integral part(Fig. 1 Fig. 2). To explore the causes of the development of ancestral theater buildings, there are mainly two reasons:Catalysis of folk opera: During the Qing Dynasty to the modern times, the prosperity of Hunan's acting activities greatly promoted the development of the theater buildings. During the Qianlong years in the Qing Dynasty, every ancestral hall had a theater building and there must be opera performances when a new theater building was built; Extension of the patriarchal system: During the Ming and Qing Dynasties, immigrants from Jiangxi moved to Hubei and Hunan. Every time when worship activities or composing genealogy began, people would gather to the ancestral hall. Operas were performed in the ancestral hall to educate people.Thus, the development of ancestral theater buildings was greatly promoted.

\subsection{The General Situation of Traditional Ancestral Theater Buildings}

\subsubsection{The Distribution of Traditional Ancestral Theater Buildings and Its Reasons}

It can be seen from the distribution map of the ancestral theater buildings in Hunan(Fig. 3) that the ancestral theater buildings are mostly distributed in the middle, east and south of Hunan. The reasons can be divided into the following points:Historical factor: After the immigrants moved to Hunan, they mainly lived on agriculture. When they got used to the area, they began to migrate to the west and south. Stable life and rich economic strength promoted the development of local ancestral theater buildings; Geographical factor: The west and south of Hunan are surrounded by mountains. The traffic is relatively inconvenient, which provides an opportunity to protect the ancestral halls. In the agrarian age, the science was not developed.Therefore, a supernatural belief or superstition was needed to improve the confidence of the residential location, which was called Fengshui; Cultural factor: The Yuan River flows past the west of Hunan. Due to its unique cultural form, 
it was named as the "source of Chinese civilization from the south." As a minority area, the patriarchal concept is relatively strong, the people are simple and honest.

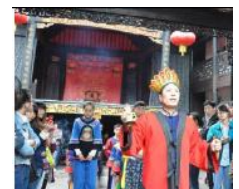

Fig. 1: The worship ceremony of the Yangs' ancestral hall in Fenghuang

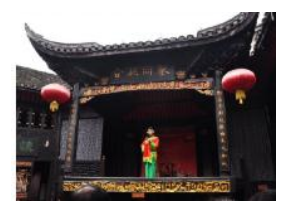

Fig. 2: The opera in the theater of the Yangs' ancestral hall

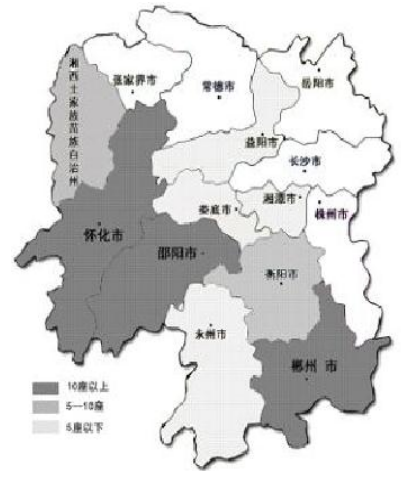

Fig. 3: The distribution map of the ancestral theater buildings in Hunan

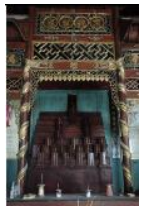

Fig. 4: The tablet of the Duans' ancestral hall

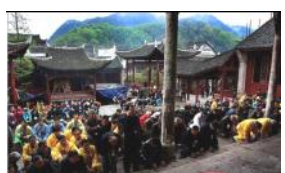

Fig. 5: The worship ceremony of the ancestral hall

\subsubsection{The Function of Traditional Ancestral Theater Buildings}

The ancestral hall is the core of a family. Its basic function is to worship ancestral tablets(Fig. 4) and hold worship ceremonies regularly(Fig. 5). The opera the ancestral halls performed was about promoting filial piety etiquette and flatters of the ancestors. The opera worshiped the ancestors and entertained the people at the same time. As the center of the family, the ancestral hall maintained the blood ties by the annual spring and autumn worship. In this way, the internal cohesion was increased and it became easier to control people in the family. In the blood type village, the ancestral hall is the comprehensive manager of the village. It interfered the economy, politics, culture, etc to a certain extent.

\section{The Architectural Form of Traditional Ancestral Theater Buildings in Hunan}

\subsection{Overall Layout}

The ancestral hall is of the highest status in the blood type village. Its site selection considers Fengshui and landscape a lot, so the site of the ancestral hall is usually in the village center with good Fengshui.

\subsubsection{Plan's Axis of Symmetry}

Restricted by the patriarchal clan system and feudal etiquette, ancestral halls are generally axisymmetric form rigorously. On the central axis, the gate, stage, courtyard, memorial hall and the sleeping chambers are arranged in turn, such as the Huangs' ancestral hall(Fig. 6). The ancestral hall(Fig. 7) usually faces north. This is because the ancients regarded the south a lot. The memorial hall facing south reflects the respect for the ancestors. The ancestral hall is mostly divided into three parts. The first part is the gate and the stage. The second part is the memorial hall which was used for worship activities. The third part is the sleeping chambers, used for depositing the ancestral tablets.

\subsubsection{Diversified Combination of Courtyards}

The ancestral theater buildings are mainly courtyards, with a characteristic of enclosed to the outside but open to the inside. According to the performance space and viewing space, the ancestral theater buildings form diversified combination of courtyards. Three types are commonly seen(TABLE I): Single side corridor: This type has no side corridors. There is only a main hall across the stage. The audience usually view the performance in the courtyard and the main hall; Three sides enclosure: The stage, the real drama are connected to the corridors at both sides, in order to show the prominent status of the main hall; Four sides enclosure: The stage, corridors of both sides and the main hall are tightly connected, forming cloister. 
TABLE I: Combination of Courtyards

\begin{tabular}{|c|c|c|c|c|}
\hline Type & Single side corridor & Three sides enclosure & Four sides enclosure & \\
\hline $\begin{array}{l}\text { Charact } \\
\text { eristics }\end{array}$ & $\begin{array}{l}\text { No side } \\
\text { corridors,performances are } \\
\text { viewed in the courtyard and } \\
\text { the main hall. }\end{array}$ & $\begin{array}{l}\text { The stage, the real } \\
\text { drama are connected } \\
\text { to the corridors at } \\
\text { both sides. }\end{array}$ & $\begin{array}{l}\text { The stage, corridors of } \\
\text { both sides and the main } \\
\text { hall are tightly } \\
\text { connected, forming } \\
\text { cloister. }\end{array}$ & 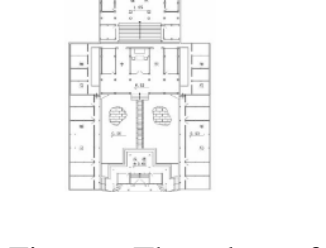 \\
\hline Graphs & & & & $\begin{array}{l}\text { Fig. 6: The plan of } \\
\text { the Huangs' ancestral } \\
\text { hall }\end{array}$ \\
\hline & & & & $\begin{array}{l}\text { Fig. 7: The plan of } \\
\text { Tianlin ancestral hall } \\
\text { in Lingjiao }\end{array}$ \\
\hline
\end{tabular}

\subsection{Substantial Elements}

The substantial elements of ancestral theater buildings(Fig. 8) mainly consist of the stage(used for performing), the real drama(room for performers to rest and makeup ), the corridor and main hall(used for the viewing of the audience).

\subsubsection{The Stage}

The performance space of the ancestral theater building is the stage, which acts as a carrier of opera performance.

\section{(1) Type}

According to the book "The History of Chinese Ancient Theater" , the stage is mainly divided into three types(TABLE II):Single stage:The roof of single stage is unified. Its structural form is simple as well.The roof structure and the supporting structure are complete and unified system; Double stage tandem type:With the development of opera art, the number of actors has increased, which needs more background space.The stage area expands gradually. The front stage and back stage are separated eventually by partition doors and share different structure system; Stage with penthouse: There are penthouses on both sides of the stage, which are used for the real drama. The partition doors are moved backwards and achieve more performance space.

TABLE II: Types of Stage

\begin{tabular}{|c|c|c|c|c|}
\hline Type & Single stage & $\begin{array}{l}\text { Double stage tandem } \\
\text { type }\end{array}$ & $\begin{array}{ll}\text { Stage } & \text { with } \\
\text { penthouse } & \end{array}$ & 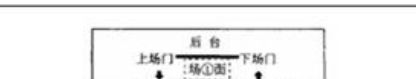 \\
\hline \multirow[t]{2}{*}{ Characteristics } & \multirow{2}{*}{$\begin{array}{l}\text { The roof structure } \\
\text { and the supporting } \\
\text { structure are } \\
\text { complete and } \\
\text { unified system. }\end{array}$} & \multirow{2}{*}{$\begin{array}{l}\text { The front stage and } \\
\text { back stage are } \\
\text { separated by partition } \\
\text { doors and share } \\
\text { different structure } \\
\text { system. }\end{array}$} & \multirow[t]{2}{*}{$\begin{array}{l}\text { Penthouses on } \\
\text { both sides of the } \\
\text { stage, which are } \\
\text { used for the real } \\
\text { drama. }\end{array}$} & 的 \\
\hline & & & & $\begin{array}{l}\text { Fig. 8: Plan layout of traditional } \\
\text { theater buildings }\end{array}$ \\
\hline \multirow[t]{2}{*}{ Graphs } & & & & \\
\hline & & & & $\begin{array}{l}\text { Fig. 9: Four plan types of } \\
\text { traditional theater buildings }\end{array}$ \\
\hline
\end{tabular}




\section{(2) Plan Composition}

According to the functions, traditional theater buildings can be divided into front stage, back stage, door to enter the stage and door to get off the stage.The front stage and back stage are often separated by partition doors. There is a door on each side of the stage for performers to enter the stage and get off the stage. On the basis of "The History of Chinese Theater", the plan of stages can be divided into four types(Fig. 9):Firstly,the plan of the stage is rectangle and there are only front and back stages; Secondly and thirdly, penthouses appear and the area of the back stage increases, extending to both sides. The audience an view the performance from three sides; Penthouses locate on both sides of the stage and there is only one corridor in the back stage.

\section{(3) Elevation Characteristics}

The elevation elements mainly consist of the roof, housing body(girder, pillars and proscenium box) and the platform. The roof is the fifth elevation of the building. The roof of the existing ancestral theater building is mostly gable and hip roof with single eaves. Other forms such as gable and hip roof with double eaves or six horned helmets also exist. The back stage usually has a gabled roof, with the separation of front and back stage (TABLE III).

TABLE III: Shape of Roof

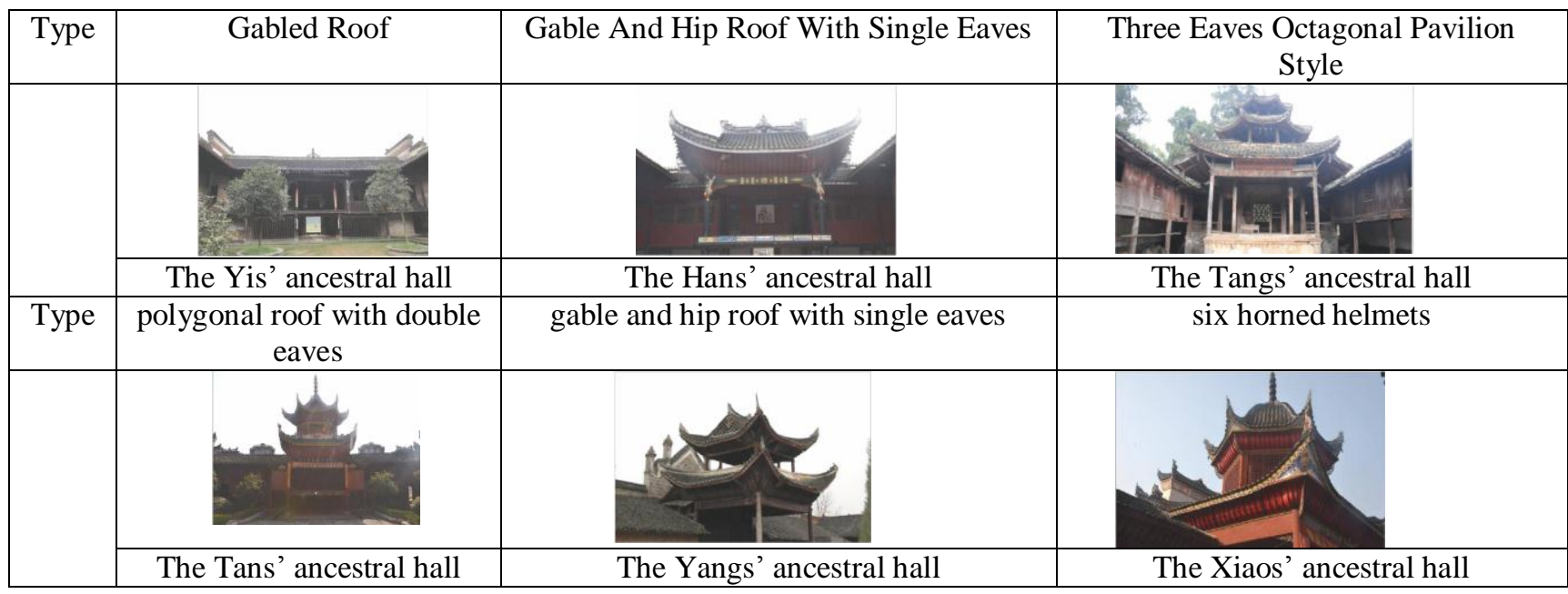

The housing body contains architrave, beams, brackets, walls and pillars etc. During the Ming and Qing Dynasties, the column grid mostly adopted the form of minus column and shifting column. This is because the performance space needs to avoid the occlusion of sight by the columns.

The structure of the traditional stage is mainly wooden beam framework (Fig. 10 Fig. 11). The composition of beams transfers the load from the beams to the pillars. Thus, all the stress components are in the best condition.

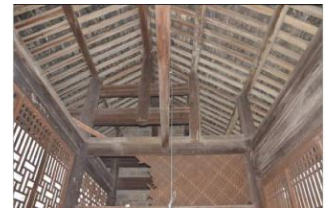

Fig. 10: The Duans' ancestral hall

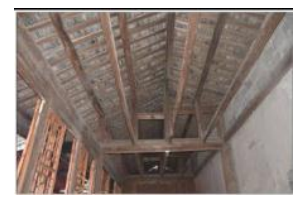

Fig. 11: The Hans' ancestral hall

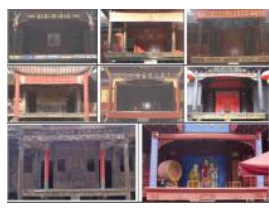

Fig. 12: The proscenium box

The proscenium box(Fig. 12) is composed of the eave columns, architrave and edge of the stage. It is the performance box and can be divided into two types:Viewing from one side: There are gables on both sides of the stage. Most stages in the north of China adopt this type; Viewing from three sides: The viewing angle of this type is wider and the interaction between the performer and the audience can be more frequent. Moreover, it is good for ventilation. This kind of stage mostly exists in the south of China. 
The platform is an important part of the stage with waterproof function. It lifted the stage to meet the need of viewing. It can be divided into two parts:

- Solid platform(Fig. 13): The bottom of the stage is composed of entities, such as brick, stone and earth. People do not pass below the solid platform. The stage is built separately, far from the gate. The height of the platform is low, which is usually seen in small courtyard space, convenient for people to view opera in the yard.

- Empty platform(Fig. 14):The bottom of the stage is supported by pillars. This is because many stages and gates are combined together. With the stage overhead, people can pass below with ease.

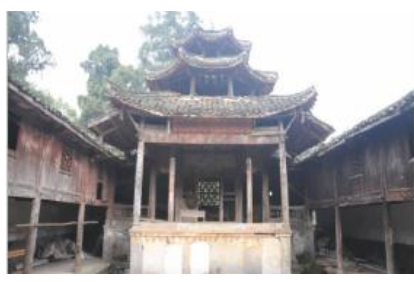

Fig. 13: Solid platform

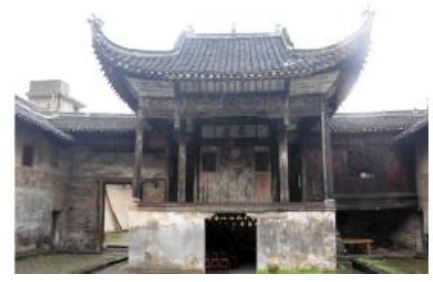

Fig. 14: Empty platform

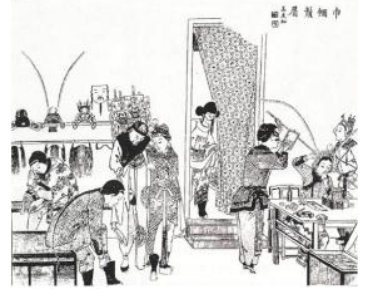

Fig. 15: The real drama

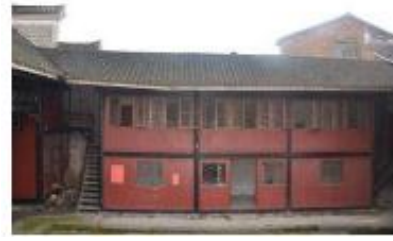

Fig. 16: The corridor

\subsubsection{The Real Drama}

The functions of the real drama (Fig. 15) are as follows:

- Restroom for performers to make up.

- Place to store props and clothing.

- Placement of band and bedding plot.

In the Qing Dynasty, penthouses used as the real drama separated from the stage and formed the shape of high in the middle and low on both sides.

\subsubsection{The Corridors}

In the courtyard enclosed by the stage, corridors and the main hall, the corridors are usually on both sides of the central axis(Fig. 16). The corridors are connected with the stage or the main hall and form a flowing space. The form of corridors are diversified. The second floor of corridor is used to view the performance, while the first floor is empty, which is convenient to pass and avoid the rain.

\subsubsection{The Main Hall}

As the viewing space of the ancestral theater building, the colonnade of the main hall is open in order to prevent the line of sight. The layout of the ancestral hall is mainly facing the south. The main hall guides the layout of other buildings. The stage is on the opposite side of the main hall so as to entertain the gods. According to its location on the axis, the main hall can be divided into two types:The first type(Fig. 17) is open to both the front and the back, which is symmetric along the central axis, with the stage behind the gate. The second type(Fig. 18) is at the end of the central axis. It combines the function of viewing and worship. In the main hall is the tablet of the ancestor.

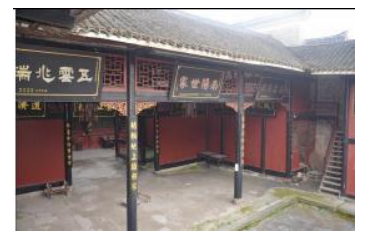

Fig. 17: The main hall of the Hans' ancestral hall

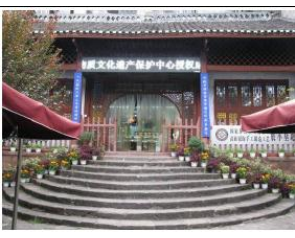

Fig. 18: The main hall of the Chens' ancestral hall

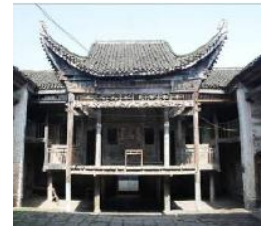

Fig. 19: The entrance of the stage 


\subsection{Spatial Pattern}

\subsubsection{The Entrance Space}

During the Ming and Qing Dynasties, the craftsmen combined the stage and the gate together in order to increase the area of the courtyard. There are often two floors in the stage. The first floor of the stage is empty and acts as the entrance. Moreover, the empty space is good for ventilation (Fig. 19).

\subsubsection{The Viewing and Performance Space}

The courtyard is the earliest place to view the opera. Afterwards, as the purpose of "entertaining god" changed into "entertaining human" , the main hall was used to view the opera. Besides, the corridors became viewing places for women and children.

The viewing and performance space can be divided into two types. The first type is to lift up the stage. Thus, the bottom of the stage, courtyard and the main hall are in a horizontal plane. The best place to view the opera is on the second floor of the corridors (Fig. 20). The second type is to keep the bottom of the stage and the courtyard in the same horizontal plane. The main hall is elevated, so the courtyard and the main hall are connected by stairs. The main hall and the corridors are therefore related. This time, the best viewing place are both the main hall and the corridors on the second floor(Fig. 21).

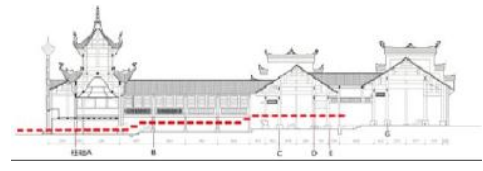

Fig. 20: The viewing and performance space of the Yangs' ancestral hall

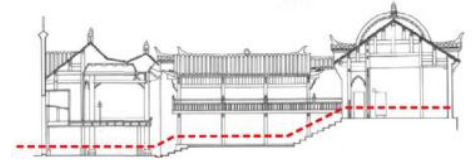

Fig. 21: The viewing and performance space of the Chens' ancestral hall

\section{Summary}

As the production of feudal patriarchal system, the ancestral theater buildings play an important role. Nowadays, many ancestral theater buildings lose their original functions, but their new functions make them come back to life again. For example, the Wangs' ancestral hall is used as a museum and the Kui Gong ancestral hall is a primary school in the countryside now. Therefore, the adaptive reuse of the ancestral theater building is also worth studying.

\section{Acknowledgements}

This paper is supported by the National Natural Science Fund of China, code 51378230.

\section{References}

[1] Li Xiaofeng, Tan Gangyi.Dwellings in HuBei and Hunan [M].Beijing:China Architecture\& Building Press, 2009

[2] Hunan folk customs Report. Hunan Bureau of investigation, 1912

[3] Hunan drama test (the first set).ChangSha,1920

[4] Zhang Guoxiong.The main flow and staging of Chinese immigrants in the history of China[J], Journal of Peking University,1996(2)

[5] Chen Zhihua, Li Qiuxiang.Preliminary study on Chinese Vernacular Architecture [M].Beijing: tsinghua university press, 2012

[6] Zhou Huabin, Zhu Lianqun.The history of Chinese Theater [M].Beijing: Beijing Broadcasting Institute press,2003

[7] Guo Guanglan, Song Liangxi. Series of Chinese guildhall-----Xi Qin Guildhall[M].Chongqing: Chong Qing press, 2006

[8] Wang Jiqing. A brief study on the construction of Chinese traditional opera field two------ characteristics of theater buildings[J].Journal of Tongji University,2002(02) 